University of Nebraska - Lincoln

DigitalCommons@University of Nebraska - Lincoln

4-17-1990

\title{
Hermeneutica gloriae vs. hermeneutica crucis: Sebastian Franck and Martin Luther on the Clarity of Scripture
}

Priscilla A. Hayden-Roy

University of Nebraska-Lincoln, phayden-roy1@unl.edu

Follow this and additional works at: https://digitalcommons.unl.edu/modlanggerman

Part of the Modern Languages Commons

Hayden-Roy, Priscilla A., "Hermeneutica gloriae vs. hermeneutica crucis: Sebastian Franck and Martin Luther on the Clarity of Scripture" (1990). German Language and Literature Papers. 24.

https://digitalcommons.unl.edu/modlanggerman/24

This Article is brought to you for free and open access by the Modern Languages and Literatures, Department of at DigitalCommons@University of Nebraska - Lincoln. It has been accepted for inclusion in German Language and Literature Papers by an authorized administrator of DigitalCommons@University of Nebraska - Lincoln. 


\section{Hermeneutica gloriae vs. hermeneutica crucis Sebastian Franck and Martin Luther on the Clarity of Scripture*}

\section{By Priscilla Hayden-Roy}

Martin Luther maintains throughout his work, and with special emphasis in On the Bondage of the Will, that Scripture is clear. Unlike Erasmus, who warns that we should avoid obscure parts of Scripture that, like the Cave of Corycos, would lure us too close to terrors beyond our comprehension, ${ }^{1}$ Luther argues that Scripture has been placed in the clearest light by the coming of Christ, in whom all of Scripture's mysteries have been revealed. ${ }^{2}$ If we were to look for a

* The basis for this article was a paper presented at the quinquecentennial celebration of Luther's birth sponsored by the Center for Reformation Research, St. Louis, in June, 1983. I am grateful for helpful suggestions since then from Professor Steven Ozment and from my husband, Dr. Patrick Hayden-Roy.-Abbreviations: LW: Luther's Works, 55 vols. (St.Louis, Philadelphia: 1955-1975).-ME: Sebastian Franck: Das Theür und Künstlich Büchlin Morie Encomion das ist Ein Lob der Thorhait / von Erasmo Roterodamo schimpfflich gespilt / zü lesen nit weniger nützlich / dan lieblich verteütscht (Ulm: Hans Varnier, s.a. [1534]). - Paradoxa: Sebastian Franck: Paradoxa ducenta octoginta / das ist CCLXXX. Wunderred und gleichsam Raterschafft / aus der H. Schrifft (Ulm: Johann Varnier, 1534). - WA: D. Martin Luthers Werke: Kritische Gesamtausgabe (Weimar, 1883-).

1. See Erasmus: De libero arbitrio; Opera omnia, 9 (Hildesheim, 1963, repr. of the 1706 ed.): $1216 . C$.

2. See Luther: De servo arbitrio; WA 18: 606.24-28 ( $L W$ 33: 25 f.). For the debate between Erasmus and Luther on the clarity of Scripture see: Rudolf Hermann: "Von der Klarheit der Heiligen Schrift. Untersuchungen und Erörterungen über Luthers Lehre von der Schrift in "De servo arbitrio," in: Rudolf Hermann: Studien zur Theologie Luthers und des Luthertums. Gesammelte und nachgelassene Werke, 2, ed. Horst Beintker (Göttingen, 1981): 170-255; Friedrich Beisser: Claritas scripturae bei Martin Luther (Göttingen, 1966), esp. 75-130; Ernst Wolf: "Über 'Klarheit der Heiligen Schrift' nach Luthers 'De servo arbitrio," Theologische Literaturzeitung 92 (1967): 721-730; Otto Kuss: "Über die Klarheit der Schrift. Historische und hermeneutische Überlegungen zu der Kontroverse des Erasmus und des Luther über den freien oder versklavten Willen," in: Schriftauslegung. Beiträge zur Hermeneutik des Neuen Testamentes und im Neuen Testament, ed. Josef Ernst (Paderborn, 1972), 89-149; Erling T.Teigen: "The Clarity of Scripture and Hermeneutical Principles in the Lutheran Confessions," Concordia Theological Quarterly 46 (1982) 147-166; Peter Neuner, Friedrich Schröger: "Luthers These von der Klarheit der Schrift," Theologie und Glaube 74 (1984): 39-58. For brief but instructive discussion, see Peter Meinhold: Luthers Sprachphilosophie (Berlin, 1958), esp. $34 \mathrm{f}$. (see ibid., 21-27, for Meinhold's differentiation between Luther's and the Spiritualists' understanding of language, contemporary of Luther's to represent the opposite pole, the obscurity or ambiguity of Scripture, it would not be Erasmus for whom Corycian caverns become the hermeneutical starting point of Scriptural exegesis. The spelunker of the darkened word is Sebastian Franck. ${ }^{3}$ For this Spiritualist the truth of Scripture is hidden: its meaning lies in puzzles and paradoxes decipherable only by those few spiritually-minded members of the invisible church.

In the course of this discussion we shall examine the anthropological faculties on which Franck and Luther base human knowledge of spiritual matters and how both thinkers define the nature and content of this knowledge. By this means we shall arrive at the concept of the clarity of Scripture in the thought of Franck (I) and Luther (II).

I.

The Spiritualists of the 16th century were heirs to a tradition of mystical theology in which the anthropological seat of spiritual enlightenment was located in the synteresis voluntatis et rationalis, or the Seelenfünklein.4 Sebastian Franck stands in this tradition and carries it perhaps with the greatest rigor of his contemporaries to its logical conclusion.

Before we examine the hermeneutical implications of this anthropological faculty we must situate it in Franck's thought, specifically in the framework of Neo-Platonic mystical theology as he received it from the 14th century Dominican preacher, Johannes Tauler (1300-61), and the 15th century anonymous tract, the Theologia Deutsch. ${ }^{6}$

Franck begins with an ontological concept of God. God is being, the simple unity in which all things exist without differences, an ineffable, inscrutable,

using Franck as the representative of the latter); Karl-Heinz zur Muhlen: Nos extra nos: Luthers Theologie zwischen Mystik und Scholastik (Tübingen, 1972), esp. 235-243 (this book was especially helpful for my work on Luther)

3. For bibliographical information on Franck, see Christoph Dejung's bibliography: "Sebastian Franck," in Bibliotheca Dissidentium, 7 (Baden-Baden, 1986): 39-119; this work updates Klaus Kaczerowsky's Sebastian Franck. Bibliographie (Wiesbaden, 1976). See also Patrick Hayden-Roy: The Inner Word and the Outer World: A Biography of Sebastian Franck (Ph. D. diss., Stanford University, 1988).

4. See Steven E. Ozment: Mysticism and Dissent: Religious Ideology and Social Protest in the Sixteenth Century (New Haven, 1973), esp. 1-13.

5. Ibid., $144 \mathrm{f}$.

S. Franck quoted both sources frequently. He also wrote a Latin paraphrase of the Theologia Deutsch; see Alfred Hegler: Sebastian Francks lateinische Paraphrase der Deutschen Theologie (Tübingen, 1901). 
uncreated Word superceding all particular knowledge and all limitations: "God is all in all, the nature, the pleasure, the being of all being, virtue of all virtue, in whom all things are contained. All things live and move in him, by his hand he imparts being to [weset] all things and rules over them." This uncreated being emanates divine essence into the world by speaking the divine word. By this word the invisible, transcendent spirit enters into and sustains the finite, material world:

"Now the tool, instrument and means whereby God created all things is this almighty word alone, which was with God in the beginning and was God himself ... Therefore there is only one word of God in which all things subsist and are supported, sustained and nourished, [even] as they are created. Alone this is necessary - that all things must proceed from this [word]." ${ }^{\text {" }}$ The relationship between the word and the world carries over into language: the inner word, or res significata, is contained in the outer word (the letter), or res significans. Just as the world derives its being from the divine word, so the letter has its true signification in the spiritual, inner word.

How do these basic assumptions in Franck's thought determine how he addresses the soteriological question? In order to gain access to God one must turn away from the outer world, from the particulars; one must turn away from outer sacraments, from the written word, from the dead letter, and plunge into the realm of the invisible spirit, the uncreated word. This would be an impossible task if humankind were defined strictly as non-spirit, that is, if the results of original sin were understood to have corrupted humankind utterly. However, by defining God as being, and creation as the emanation of divine being, the mere fact of one's "beingness," of entity, precludes the possibility of utter sinfulness, of nothingness. The spark of divine being, the uncreated word of God, while obscured by the nothingness of matter and ignored by a sinful will that tends away from the source of being, nonetheless dwells eternally, indestructibly in the highest part of the soul. Writes Franck: "God, in the wisdom of his nature and being, laid a form, spark [zundel], trace, light, and image in the human heart, in which God sees himself. And Scripture calls this image of God,

7. Paradoxa, No.91 (P3v): "Gott is alles in allen / die natur / das glück aller wesen Wesen / aller tugent Tugent / inn jm ist alle ding beschlossen. Es regt sich / webt / und lebt alles inn $\mathrm{jm} /$ in seiner handt weset und wendet er alle ding."

8. Paradoxa, No. 50 (J1v): "Nun der werckzeug / instrument / und mittel dar durch gott alle ding geschaffen hat / ist allein disz almechtig wort / das im anfang was bei Gott / und Gott ia selbs ... Darumb ist auch nur ain wort gottes in dem alle ding bestehen / getragen / erhalten / uñ ernärt werdē / wie erschaffen. Das ist allain von nòten / ausz dem allain můsz alles gehen." and this divine character of God's word, will, son, seed, hand, light, life, and the truth in us. Thus we are capable of being divine [gottes vahig], and to a certain extent we are, in accordance with this image, of divine nature." With the mystical notion of the inner spark (zundel, or synteresis) Franck posits a continuum between God and the individual. The spark is both an extension of divine being, and an epistemological faculty for spiritual knowledge. When this faculty is activated, the individual grasps spiritual truths immediately: the need for any mediating structures between the individual and God is obviated. Franck even subjects his Christology to this synteresis theology. Christ's task was not to atone for sin, but to remind humankind of the word within their hearts: "But the same [God's word] is contained in all human hearts, Deut. 30 [:14], Romans $10[: 8]$, although few read the tables of their hearts. Therefore Christ came, God became a person, so that he point us toward these tables and remind us of that which was already in us, but of which we wished to know nothing." ${ }^{10}$ Christ demonstrated to humankind the possibility of living according to this inner nature and thus transcending the limitations of the flesh. Franck insists that the diastasis between inner and outer word be maintained strictly even in the deus incamatus. Christ is more Christ according to the inner person than according to the outer. According to the flesh he is only a picture of God, but according to the spirit he is the Word and God himself. ${ }^{11}$.

9. Paradoxa, No.102 (R3v): "Gott hat seiner weyszhait art und wesens ain mủster zundel / gespür / liecht / und bild / in des menschen hertz gelegt / dariñ sich gott selbs sihet. Und disz bild gottes / uñ Göttlichen nent die Schrifft etwan gotes wort / willen / sun / samen / handt / liecht / leben / die wahrhait in uns. Also dz wir gottes vảhig / und etlicher masz nach disem bild / gòttlicher art sind."

10. Paradoxa, No.118 (T4v): "Dasselbig aber ist in aller menschen hertz Deur. 30. Roma. 10. eingewickelt / ob schon gar wenig die Taffel jres hertzen lesen / und darumb Christus kommen ist / Got ain Mensch worden / das er uns in dise Taffel weise / und eriñert des / so vorhin in uns war / wir aber nit wissen wolten."

11. Paradoxa, No. 99 (R1v): "Und nach disem besten tail der gotthait / ist Christus mer Christus / dann nach dem eüssern schwächsten teil des flaischs / wie ain mensch nach dem innern menschen mer ain mensch ist / dañ nach dem eüsseren / da er nur ain bildlich mensch ist / unnd allain ain figur des rechten wesentlichen menschens Also ist Christus nach dem flaisch nur ain bild uñ auszdruck Gottes / Heb. 1. Nach dem gaist aber unnd gotthait / das Wort und gott selbs / Joan. 1." - On Franck's Christology, see Alfred Hegler: Geist und Schrift bei Sebastian Franck: Eine Studie zur Geschichte des Spiritualismus in der Reformationszeit (Freiburg i.B., 1892), esp. 185-202. Part of Franck's polemic against the magisterial reformers was Christological: they clung, according to Franck, too much to Christ's flesh, rather than to his spirit. As Hegler notes (192f.), this criticism attacked specifically the doctrine of satisfaction; Franck condemned this notion of salvation extra nos; because it encouraged moral turpitude. 
This same argument carries over to the hermeneutical discussion. Just as Christ did not become flesh, but rather was covered by it like a shawl, or rind, or blanket, ${ }^{12}$ in the same way the divine Word does not really and essentially become Scripture. Franck explicitly refutes the concept of predicatio identica de diversis naturis in this context. ${ }^{13} \mathrm{He}$ argues that the diastasis between flesh and spirit makes any essential commingling between the two impossible. For this reason the outer word, including Scripture and all the teachings of the fathers, cannot mediate between God and the soul. At most these words "bear witness to" the inner, invisible Word. ${ }^{14}$ The individual must forsake them and read the tables of his heart inscribed directly by the spirit of God.

This deficiency of the outer word is no stranger to orthodox medieval theology. Augustinian hermeneutics, which dominated medieval hermeneutics, distinguished between the word in its merely significative function, the res significans, and the transcendent reality, the res significata toward which the word pointed. Thus the sign belonged to the domain of the sensible, the flesh, while the res significata was located in the intelligible or spiritual realm. ${ }^{15}$ Ebeling has noted that the Scholastic tradition underlines the inadequacy of linguistic communication by maintaining that: "... the true means of grace is not the word but the sacrament. For the word keeps man at a distance from God and God at a distance from man. The sacrament, however, unifies man with the divine itself. Grace is infused into man in form of a created reality, as habitus of the soul; it becomes a property (virtus) of man ... To this corresponds, moreover, that the word basically [is] considered as weak and dark. It is inadequate and must be

12. $M E$ ("Encomium: Ein Lob des Thoreschten Götlichen worts / was das sei"), t2r: "Wie nun das flaisch / das Wort nit ist gewesen / sonder ain deck unnd grosses sacrament des Worts. Also ist die Schrifft aigentlich nit das Wort / sonder die schal / rind / und deck oder sacrament des worts."

13. $M E$ ("Encomium"), t2r: "Das Wort ist gleichwol flaisch worden / durch die annemung / aber nit durch die vermischung. Also ist auch das Wort die Schrifft worden / nit warlich und wesenlicher Predication (predicatione identica) sonder als in ainem sigel." See also below, n. 45 .

14. On Scripture as "witness" (Zeugnis) of the Word, see Hegler, Geist und Schrift, esp. 223-228. As Hegler notes (225f.), in this concept of "Zeugnis" lies "ihr [Scripture's] positiver Wert und ihre Grenze. Die Schrift soll uns als ein Zeugnis von dem unmittelbaren Wirken des göttlichen Geistes in uns selbst und in Gott weisen; so wird manchmal ihr Zeugnis dem inneren des Gewissens koordiniert. ... Das Zeugnis vermittelt nicht selbst die Sache ... Was Zeugnis ist, hat streng genommen keine heilsschaffende Kraft, darum kann es auch nicht die höchste Auktorität sein."

15. See Gerhard Ebeling: "Hermeneutik," in: Die Religion in Geschichte und Gegenwart, (3rd ed.) 3 (Tübingen, 1959): 249. explained." ${ }^{16}$ Thus Scholastic hermeneutics and the hermeneutics of heterodox mysticism are to be distinguished not in terms of the former's "higher" view of the word, but rather in terms of how each claims to have access to the inner word hidden in the outer word. On the one hand enlightenment requires the special grace of church and sacraments, on the other immediate illumination circumvents all need of institutional mediators of the word.

While direct access to the divine is a human possibility according to Franck, he seems to have been obsessed with the observation that this potential remains unrealized in the vast majority of people. They do not read the tables of their hearts, but instead define themselves and God according to the outer word, the letter. They mistake outer ceremonies for true spiritual worship-and here Franck includes the whole scope of divinely instituted sacrificial rites of the Old Testament and the ceremonial rituals of the medieval church. ${ }^{17}$ Because these are visible and outward, they are of the flesh, and therefore are categorically opposed to true spiritual worship. Only a scattered minority of spirituallyminded persons perceives the invisible realm of God. For these the church remains invisible, unincarnated. ${ }^{18}$ Here the consistency of Franck's thought supercedes that of his contemporary Spiritualists, for whom the invisible Spirit invariably spilled over into visible, "fleshly" manifestations, be they sects, the Münster theocracy, or the Peasants' War. Franck's spiritually-minded persons discover the Word not in visible groups, not in political action, not in fixed words of doctrine, but hidden in paradoxes and puzzles. ${ }^{19}$ They know that

16. Gerhard Ebeling: "The New Hermeneutics and the Early Luther," Theology Today 21 (1964): 45

17. Paradoxa, No.89 (O4r): "Die Welt aber so zů mal in argem ligt / und Gott wie er ist nit erkennet / weisz sie von kainem andern Gotsdienst / dann von eüsserlichem ceremonischem / Judischem gotsdienst / mit singen / wallen / beten / Pater noster tragen / Kirchen gehen / fasten / Bildern / unnd allerlai Ceremonien."

18. Paradoxa, Introduction, $5 \mathrm{v}$ : "Weil die Kirch nit etwan ein sonderer hauff / und fingerzaige sect ist / an Element / zeit / person / und statt gebunden / sonder ain gaistlicher onsichtbarer leib / aller glieder Christi / aus gott geborn / und in ainem sin / gaist / und glauben / aber nit in ainer statt / oder etwa an einem ort eüsserlich versamlet / das man sie sehen / und mit fingern móge zaigen / sonder die wir glauben / uñ nit sehen / dañ mit gleich gaistlichen augen des gemuts / und innern menschens / Nämlich / die versamlung und gemain aller recht gots frummen und gủthertzigen / neller menschen / in aller Welt / durch den Hailigen gaist / in dem fried gottes / mit dem band der lieb zủsamen gürt / ausser deren kain hail / Christus / Gott / verstandt der Schrifft / H. gaist / noch Euangeliū ist."

19. Thus Franck explains the title of his Paradoxa (Introduction, $1 \mathrm{v}-2 \mathrm{r}$ ): “Nu hab ich disz mein Philosophei Paradoxa intituliert / und Paradoxum ain Wunderred / oder Wunderwort / verteütscht / weil die Theologei / der recht siñ der Schrifft (so allain gottes 
every word can be understood either according to the spririt or the flesh. Each res significans is equivocal, or to use Franck's more visual designation, every word is Y-shaped: "All things are equivocal [zwaierlai], right and wrong. These are equivocal: love, prayer, faith, detachedness, zeal-everything. Thus it does not suffice to pray, fast, believe, know, etc., because all things are split, they are forked like the upsilon, the letter of Pythagorus, ' $\mathrm{Y}$ ', which Virgil interpreted as the crossroads where the two paths of virtue and vice part." ${ }^{20}$ The res significans points to two res significatae: a spiritual res, which is the invisible, true being of the sign, and the fleshly res, which is the visible, false meaning given to the sign by the world. The spiritually-minded are able to discover the inner res by "judging according to the opposite," that is, by reversing the outer, fleshly meaning given the word by the world: "For all things are different in truth from their appearance viewed from the outside. In all things God holds the counterpart of the world and judges according to the opposite. Thus as the world holds, names, believes, speaks, wills one thing, so when you grasp the opposite, the counter-judgment, you have grasped God's Word, wisdom and will." 21 So absolutely opposed to each other are the two meanings of the word that a simple reversal of language according to the definitions given by what Franck would call "outer," "worldly" political and ecclesiastical authorities, brings one to that inner meaning held in the heart. ${ }^{22}$ For the spiritually-minded

Wort ist) nichts ist dañ ain ewig Paradoxū / wider allen wahn / schein / glauben / und achtung der gantzen welt / gewisz und waar."

20. Paradoxa, No.60 (J4r): "Es ist alle ding zwaierlai / recht uñ unrecht / Es ist zwaierlai / liebe / gebet / glaub / gelassenhait / eifer / und alles / Darumb ist es nit gnưg / betten / fasten / glauben / wissen / etc / Dann ist alle ding gespalten / unnd ain gabel / wie das ypsilon / der buichstab Pythagore / y / welchen Vergilius für die wegschaid / und zwen weg auszlegt / nemlich der tủgent / und untugent."

21. Paradoxa, No.14 (C2r): "Dann durch aus alle ding ist anders in der warhait / dañ es von aussen an zů sehen ist nach dem schein. Gott hảlt immer zů in allen dingen mit der welt widerpart / unnd urtailt das widerspil / Darumb wie die Welt ain ding hảlt / nennet / glaubt / redt / wil etc. so ergreiff du das widerspil / und gegen urtail / so hastu Gottes wort / weyszhait / und willen ergrieffen."

22. One of countless examples of this equivocal language appears in Franck's discussion of the words "rich" and "poor" as they are defined according to the spirit and the flesh. Paradoxa, No. 35 (G4r-v): "Sum̄a got hàlt gleich eben die weisz mit den seinen / in seiner art / wie die welt pflegt zů handlen mit den jren / in jrer art / uff baiden örten wirt nur den reichen / so vorhin gnůg haben / zů getragen / geholffen / und geben / $\mathrm{Ve}[\mathrm{r}]$ stehe aber mit den reichen uñ gewaltigen in got / sonst hält es gott mit den armen / schwachen am flaisch / und ist baides zủgleich war. Gott hảlt es mit den armen und reichen / mit den gaist armen am güt und müt / und mit den gaistreichen in gott. Satan hält das widerspill / er gafft inn die höhe nach dem Reichen am flaisch / veracht die armen the Y-shaped puzzle of the word is solved, the sense is clear. However, he does not perceive the literal or conventional, grammatical sense, but rather an invisible, anti-conventional word unveiled in his heart by the spirit. Moreover, this truth can never "surface" and affix itself to language, for as soon as the truth is identified with the letter, it becomes dogma and loses its spiritual quality. The inner word must remain buried, hidden in dark, paradoxical statements. Conversely, all that can mark truth externally is linguistic obscurity, for language ultimately is incapable of presenting spiritual truth. Paradoxical language, while failing to present spiritual truth univocally, leads the spiritually-minded reader to find the spiritual, ineffable Word in his heart. Not surprisingly, then, Franck upholds Scripture not for its clear exposition of truth, but because it is a book "sealed with seven seals." ${ }^{23} \mathrm{He}$ levels criticism at the magisterial reformers, who maintain that the letter of Scripture is clear and equate Scripture with the word of God. They grasp only the fleshly letter of Scripture, says Franck, and make that Scripture into an idol by calling it divine. ${ }^{24}$

des gaists." The confusion this equivocation generates is apparent: "rich" can mean both "rich in spirit" and "rich in the flesh.". The rich in spirit are those poor in the flesh. Thus Franck can hold an apparently contradictory or paradoxical statement to be true: God treats the rich (in spirit) and the poor (in flesh) alike. The source of this equivocation lies in the spirit-flesh diastasis inherent in the word; it is exponentiated by the same diastasis in the exegete, as Hegler writes (Geist und Schrift, 77): "Die Schrift ist dunkel und ungenügend, weil sie als Buchstabe den Geist nicht zum Ausdruck bringt und der Mensch als ein aus Geist und Fleisch zusammengesetztes Wesen stets die Möglichkeit hat, sie mit den Augen des Fleisches anzusehen." For a more differentiated discussion of the role of paradox in Franck's language, see Karl Klemm: Das Paradoxon als Ausdrucksform der spekulativen Mystik Sebastian Francks (Leipzig, 1937).

23. The image of a book sealed with seven seals is taken from Revelations 5. One of Franck's books, a collection of contradicting quotations from the Bible, is entitled: Das verbütschiert mit siben Sigeln verschlossen Büch / das recht niemandt auffthin / verstehen / oder lesen kan / dann das lamb / wnd die mit dem Thaw bezaichnet / das lamb angehoren (Augsburg: Heinrich Steiner, 1539). Hegler emphasizes (Geist und Schrift, 68f.) Franck's distance to Luther at this point and notes that Franck speaks of the "clear word of holy Scripture" only ironically, when quoting an opinion differing from his own.

24. See Sebastian Franck: Chronica Zeitbuch unnd Geschichtbibell (Ulm: Hans Varnier, 1536; repr. Darmstadt, 1969), Oovi-r (lxxiiii-r): "Also machen vil yetz ein Abgott ausz der schrifft / die sy doch nit nach dem sin̄ Christi oder geist ... sunder nach dem todten bůchstabē verston allenthalben / wie sy mit hellen worten klingt und laut / Gott nit einmal bitten / das er uns sein geheymnisz (das er für war nit an weg fur die sàw in offnem bůchstaben hat gelegt / sunder vil meer mit dem verdeckt) / eer / auszleg / unnd den todten unnd tỏdtenden buichstaben / geyst und leben inn uns mach / dann die schrifft / wie gůtt sy ymmer zůr seligkeit ist / kan sy doch kein bỏsz hertz àndern oder lebendig machen / sunst weren die schrifftgelerten die frümbsten gewesen." See also Alfred Heg- 
Franck's spiritual sense is divorced from the letter to the point where revelation is completely private, incapable of being verified through any institution or dogmatic standards. The illuminati of the inner word are united in an eternal, necessarily invisible, church. The clarity of the word lies in a continuum between the heart and divine being. It cannot affix itself to the impermanence and limitation of linguistic convention, or of any historical phenomena. Thus the inner, spiritual word gives Franck access to a "hermeneutica gloriae," but at the expense of clear language. The only adequate bearer of the inner word is dark, equivocal, paradoxical language.

\section{II.}

As Franck's hermeneutics followed directly from his anthropology, the same holds true for Luther. Ozment has maintained that, "Luther's Reformation theology originates and develops as a highly polemical answer to the anthropology of late medieval theology." ${ }^{25} \mathrm{He}$ argues that Luther consistently "desubstantiates" medieval anthropological concepts, stripping them of all "natural" soteriological capability and placing the burden of salvation exclusively upon God. Luther defines human faculties not in terms of their inherent power, or an ontological similitude or identity with God, but in terms of their object, which for Luther is God's work of salvation. Thus Luther writes in his Dictata super Psalterium: "In the Holy Scriptures understanding takes its name from the object rather than from any capacity, the opposite of what is in philosophy. ... In brief this is nothing else than the wisdom of the cross of Christ, which is folly to the Gentiles and a stumbling block to the Jews, namely, to understand that the Son of God was incarnate and crucified and put to death and raised for our salvation."26 Similarly, Luther redefines memory, which in Platonic philosophy is the seat of the knowledge of eternal norms, as reflection upon the history of the saving works of God. The affectus, which in mystical theology is the

ler's discussion of Franck's criticism of this aspect of the magisterial reformers in Geist und Schrift, esp. 63-88.

25. Steven E. Ozment: Homo Spiritualis: A Comparative Study of the Anthropology of Johannes Tauler, Jean Gerson and Martin Luther (1509-16) (Leiden, 1969), 3.

26. See WA 3: 176.3-10. David C. Steinmetz writes on this passage as follows: "What Luther has in view is not an abstract knowledge of Christ or assent to a series of propositions about him, but a faithful apprehension of the saving act of God in Christ as it is directed toward the Christian and his existence in the world"; Luther and Staupitz: An Essay in the Intellectual Origins of the Protestant Reformation (Durham, 1980), 56. See also Ozment, Homo Spiritualis, 112-114. synteresis voluntatis that longs for God, becomes the hope in God's testimonies or promises. ${ }^{27}$

This shift from an inwardly situated ontological point of contact to an exclusively external source of salvation renders the human faculties soteriologically impotent. Recognition of the self as peccator, as iniustus, thus constitutes the "highest" form of self-recognition. This leads the young Luther to redefine the mystical notion of "ecstasy." No longer does it afford knowledge of the similitude between self and the godhead. In the Dictata, ecstasy occurs when the self recognizes its utter sinfulness before the righteous God..$^{28}$ Confronted with the self coram Deo, the individual recognizes his or her complete dependence upon God. Salvation lies extra se in the promises of God, which can be grasped only by faith. ${ }^{29}$ Here congruence between God and the individual is found - albeit not in greatest similitude, as in the unio mystica - but in greatest dissimilitude: "He who is 'unlike' God is one with God." ${ }^{30}$ Conversely, to posit similitude

27. See Ozment, Homo Spiritualis (110f., 114-117) on memoria and affectus. In both instances Ozment argues that for Luther it is not the power of the faculty, but the object toward which it is directed, i.e., the saving work of God extra se, which defines and supports its functioning: "Memoria is not taken by Luther as a 'quiddative' ground of the powers of the soul (any more than cor or conscientia), but as a comprehensive description of the perseverantia of the whole man as he lives meditatively (intellectus) and affectively (voluntas) in and from the opera dei, i. e. in and from a "Zeugungsgrund" which is outside himself" (ibid., 110, n.2). By contrast Franck maintains that Christ's role was to uncover the inner word already within the heart. Hegler writes on this point (Geist und Schrift, 195): "So erhält bei Franck der alte platonische Gedanke, daß alles Lernen Erinnerung ist, die Form, daß aller Erwerb der göttlichen Kraft Wiedererwerb der unsprünglich innegehabten und nur dem Bewußtsein verloren gegangenen Kraft ist. Das Licht, dessen Leuchten durch das grobe Fleisch verfinstert ist, hat Christus wieder helle gemacht."

28. For discussions of Luther's gloss in the Dictata (WA 4: 265.30-36) of Ps.115:11 ("Ego dixi in excessu meo: omnis homo mendax"), see Heiko Obermann: "Simul gemitus et raptus: Luther and Mysticism," in: The Reformation in Medieval Perspective, ed. Steven E. Ozment (Chicago, 1971), 234; and Steinmetz, Luther and Staupitz, 137-140.

29. Mühlen (Nos extra nos, $51 \mathrm{f}$.) discusses the mystical background of the notion of "exstasis extra se," noting also how the concept takes on a new definition in Luther's hands. On Luther's use of the term "raptus" Oberman writes ("Simul gemitus et raptus," 236f.): "Raptus is the reliance on the righteousness of Christ outside ourselves (extra nos) and can be described as a complete transformation into Christ (in Christum plane transformari).... Extra nos and raptus indicate that the iustitia Christi-and not our own powers -is the source and resource for our righteousness."

30. See Ozment, Homo Spiritualis, 180. Note that this recognition of self as peccator is not to be confused with the monastic virtue of humilitas; it does not function in Luther's thought as the praeparatio by which the individual would earn God's grace. Oberman makes this point ("Simul gemitus et raptus," $238 \mathrm{f}$.) with regard to the gemitus: "Gemitus 
with God, or soteriological potential in the human faculties, demonstrates nothing but the concupiscence (curvitas in se) that has perverted both spirit and flesh since the fall. ${ }^{31}$ Curved into self, the individual equates his or her own virtue with godliness. Luther's redefinition of anthropological vocabulary is in fact the beginning of his battle against "enthusiasm" as he defines it broadly in the Smalcald Articles: "Thus we shall be protected from the enthusiasts - that is, from the spiritualists who boast that they possess the spirit without and before the Word and who therefore judge, interpret, and twist the Scriptures or spoken Word according to their pleasure. ${ }^{32}$ It is a battle that first had to be directed against his own theological language holding him captive within himself. Luther replaces ontologically defined intellectual substance with substance that lies explicitly extra se in the promises of God revealed in Christ. ${ }^{33}$

This brings us to the second limitation of human knowledge. Even when enlightened by the Holy Spirit, the intellect does not grasp the deus nudus et absconditus in maiestate sua. Insofar as God has chosen to hide himself, he is not and cannot be known, as Luther insists in On the Bondage of the Will: "To the extent, therefore, that God hides himself and wills to be unknown to us, it is no business of ours." ${ }^{34}$ The concept of the deus absconditus serves as a boundary for theological inquiry ${ }^{35}$ which is to concern itself only with the deus revelatus.

... presupposes faith and does not refer to a stage of preparation or to a virginal sinproof part in man, but to the life of faith itself"; as does Ozment in his discussion of expectare and clamare as forms of praeparatio: "In this context, praeparatio has no refined Pelagian overtones. ... Crying, expectation and hope point both to the absence-the soteriologically de-substantial nature of human life - and the reality - the promises of God, 'outside' man's power" (Homo Spiritualis, 182). Steinmetz argues (Luther and Staupitz, 93) that both Luther and Staupitz "agree that humility is not a virtue prior to justification."

31. Luther's understanding of original sin as concupiscence establishes man's sinfulness as radical, persisting even after Baptism; this is in contrast to the Scholastic notion of original sin as privation, for which the sacraments compensate. Thus for Luther justification never resides within man as a habitus, but is external, in Christ. Intra se man remains a sinner. See Mühlen, Nos extra nos, 116-124.

32. The Book of Concord, ed. Theodore G. Tappert (Philadelphia, 1959), 312.

33. Gerhard Ebeling has pointed out the shift in the definition of "substance" from the quidditative understanding of medieval theology to the qualitative concept found in Luther's Dictata. Here substance is the ground under one's feet (substaculum, subsidentia); rather than being within one, it is what bears one up, namely, the hope of salvation. See his "Die Anfänge von Luthers Hermeneutik," Zeitschrift für Theologie und Kirche 48 (1951): $192 \mathrm{f}$.

34. $L W$ 33: 139. WA 18: 685.5-6: "Quatenus igitur Deus sesi abscondit et ignorari a nobis vult, nihil ad nos."

35. Thus Regin Prenter maintains: “Die betreffenden Aussagen über die Verborgen-
For this reason Luther directs an indefatigable polemic against the enthusiasts and contemplatives who, in their mystical ascent to the deus nudus, are either driven to despair (the only possible reaction to God's glory), or fall prey to the deception of the devil. ${ }^{36}$

The concept of the deus absconditus serves also to guarantee the absolute power of God. He is the will behind the God who freely chooses to bind himself to his word. The distinction between deus absconditus and deus revelatus is roughly comparable to the distinction favored by Nominalist theology between the potentia dei absoluta and the potentia dei ordinata. This distinction served likewise to free God from the necessity of the established means of grace, thus insuring that he not be construed as a debtor to humankind. Seen in light of his absolute power, God is not bound to effect salvation; by his ordained power he chooses to be bound to a particular, fixed means of grace. This much of the distinction is compatible with Luther's theology. However, having conceded hiddenness and inaccessibility to the deus absolutus, the God revealed by his ordained power was so much the more accessible to Nominalist theologians. They argued that while the individual has no condign merit which could make God his debtor, God chooses by'means of his ordained powers to accept the actions of "the one who does his best" (qui facit quod in se est) as meritorious." In his Disputation Against Scholastic Theology Luther clearly refutes this doctrine. Man's disposition towards God both morally and rationally consists in

heit Gottes sind nicht als Elemente einer aufzubauenden Gotteslehre zu behandeln, sondern eher als Marksteine, die allen theologischen Aussagen uber Gott eine Grenze ziehen, zu respektieren. Respektiert der Theologe die in jenen Aussagen markierte Grenze nicht, treibt er nicht länger echte Theologie, sondern pseudophilosophisch verdorbene Theologie." ("Luther als Theologe," in: Luther und die Theologie der Gegenwart, ed. Leif Grane et al. [Göttingen, 1977], 115.) My remarks concern the God hidden outside his revelation, rather than within it (sub contrariis). On these two usages of "hiddenness" in Luther's theology and the literature on this thorny subject, see Brain A. Gerrish: "To the Unknown God': Luther and Calvin on the Hiddenness of God," in: Brian A. Gerrish: The Old Protestantism and the New: Essays on the Reformation Heritage (Chicago, 1982), 131-149.

36. Thus Luther writes in his Genesis Commentary (WA 43: 72.24-28): "Ab eo [Christo crucifixo] cave discedas, qui enim abiecta vel neglecta humanitate, seu carne Christi, de Deo, ut monachi solebant, et nunc Suenckfeldius et alii solent, speculantur, aut ad desperationem adiguntur, oppressi claritate Maiestatis, aut iubilant stulte, ac se in coelos positos somniant, decepti a Satana, talibus praestigiis animos ludente."

37. See Heiko Oberman: "Facientibus quod in se est Deus non denegat gratiam: Robert Holcot O.P. and the Beginnings of Luther's Theology," in: The Reformation in Medieval Perspective, 119-141. 
rebellion and ignorance. ${ }^{38}$ Luther redefines the term "potentia dei ordinata" in strictly Christocentric terms. God's ordained power lies in the "incarnate Son," as he writes in the Genesis Commentary: "We must reflect on God's ordered [or ordained] power, that is, on the incarnate Son, in whom are hidden all the treasures of the Godhead (Col.2:3). Let us go to the child lying in the lap of His mother Mary and to the sacrificial victim suspended on the cross; there we shall really behold God, and there we shall look into His very heart. We shall see that $\mathrm{He}$ is compassionate and does not desire the death of the sinner, but that the sinner should 'turn from his way and live' (Ezek. 33:11)." ${ }^{39}$ It is Christ crucified and raised from the dead who is the means of salvation revealed according to God's ordained power. Thus Luther has effectively lowered the roof of spiritual knowledge from the deus absolutus (or deus absconditus) to the deus revelatus. Here the mysteries of salvation are revealed. More one need not know about God. Furthermore, even within this restricted sphere the intellect is impotent. For by nature it is curous in se and seeks salvation within. The intellect enlightened by the Holy Spirit sees the absolute difference between God and self, and only at this point can the individual respond in faith to the revealed salvation which lies extra se.

Given these restrictions, Luther's hermeneutical self-assuredness is startling. If humankind by nature is ignorant of God, and if the intellect enlightened by grace perceives only the revealed God, and if this limited knowledge itself is epistemologically foreign to the human intellect, how can Luther flatly assert that Scripture is clear? On what basis can this hermeneutical cripple make such a statement? Or is what he asserts to be clear so restricted as to make the claim trivial?

We recall that according to Augustinian hermeneutics, the outer word (res significans) served to point to the inner, spiritual meaning (res significata). The relationship of letter to meaning corresponded to that between flesh and spirit, so that the letter, because of its externalness, was judged deficient over against its spiritual, signified meaning in the mind of God. Spiritual understanding was achieved only when the intellect detached itself from the transitory realm by divine illumination and became linkened to the eternal, divine mind. Luther, however, maintains that the final res significata behind all res significantes is not

38. Ibid., 130. For the relevant portions of the Disputatio, see WA 1: 225-226 ( $L W 31$ : 11).

39. LW 3: 276f. (WA 43: 73.3-8). Significantly, this admonition follows Luther's warning against the enthusiastic speculations of the contemplative tradition and of his contemporary, Caspar von Schwenckfeld. (See above, n. 36.) the mind of God, but the Word of God, deus revelatus in Jesus Christ. He places both res significans and res significata within the potentia dei ordinata. There is no break between visible flesh and obscured, transcendent spirit as the sign points to its meaning. Both sign and signified are flesh, revealed. For this reason Luther can maintain that Scripture is clear.

Yet the problem remains that despite the clarity of Scripture, a soteriologically impotent intellect cannot grasp this clarity. Thus Luther distinguishes between two kinds of clarity in On the Bondage of the Will: "There are two kinds of clarity in Scripture ...: one external and pertaining to the ministry of the Word, the other located in the understanding of the heart. If you speak of the internal clarity, no man perceives one iota of what is in the Scriptures unless he has the Spirit of God. All men have a darkened heart, so that even if they can recite everything in Scripture, and know how to quote it, yet they apprehend and truly understand nothing of it. ... For the Spirit is required for the understanding of Scripture, both as a whole and in any part of it. If, on the other hand, you speak of the external clarity, nothing at all is left obscure or ambiguous, but everything there is in the Scriptures has been brought out by the Word into the most definite light, and published to all the world. " 10 External clarity pertains to the grammatical clarity of the words (signa, or res significantes) as they illumine Christ (the res, or res significata). Here Luther claims that we find indisputable clarity except in those places obscured "due to our ignorance of certain terms and grammatical particulars," and "not to the majesty of the subject." ${ }^{41} \mathrm{He}$ adds that when the res, Christ, is in the light, it does not matter if one or the other sign (signum) is in darkness, just as a fountain in the market place is clearly visible even if it cannot be seen from a side alley. ${ }^{42}$ Philological investigation obviously takes a leading role in furthering external clarity. Luther's freely acknowledged indebtedness to humanistic philology as well as his own translating of Scripture are prompted by his concern for augmenting the external clarity of Scripture and making it accessible to the common folk. But what does Luther mean by internal clarity? Only those who have the spirit, he says, have internal clarity. Is Luther introducing with this category an epistemological point of contact between God and the believer? Does a hermeneutica gloriae finally sneak into Luther's understanding of the

40. $L W 33: 28$ (WA 18: 609.4-9,11-14).

41. $L W 33: 25$ (WA 18: 606.22-24).

42. WA 18: 606.35-39 ( $L W 33: 26$ ): "Iam nihil refert, si res sit in luce, an aliquod eius signum sit in tenebris, cum iterim multa alia eiusdem signa sint in luce. Quis dicit fontem publicum non esse in luce, quod hi qui in angiporto sunt, illum non vident, cum omnes qui sunt in foro videant?" 
clarity of Scriptures? Despite the similarity in diction between Luther and Franck at this point, their ideas diverge. Luther's internal clarity rests on his dual anthropology of simul iustus et peccator. It proceeds not from the believer's own intellect, but from the Holy Spirit extra se. The heart of man is darkened because it is concupiscent, curvus in se, and is ready to be enlightened only when it recognizes its own inability to produce a saving res significata from within. The believer must see his own intellect condemned under the cross of Christ as a source of ultimate signification; he must turn extra se and receive in faith the message of salvation as substance ontologically and epistemologically foreign to himself. The burden of signification falls on God, while the believer simply confesses, or "repeats," 43 the res significans, the promise of salvation.

Luther's concept of the clarity of Scripture serves as a barrier for human speculation: nothing beyond the deus revelatus is of any concern to humankind. This concept also guarantees that human intellect be defined as soteriologically impotent: it is not required to possess the spiritual meaning of the outer word, which would be just one more sensus proprius, but to accept that res significata extra se given by God. This "hermeneutics of the cross" underlies Luther's debate with Erasmus on free will and the debate with Zwingli and the enthusiasts on the Eucharist; it is even at the root of his disagreement with the papacy. In all cases Luther argues that his opponents postulate the obscurity of the external word in order to place themselves as judge over the word, making themselves subject and source of the res significata. ${ }^{44}$ They trespass beyond the bounds of theological hermeneutics set by the potentia dei ordinata in that they make it their duty to define what is behind the word. Luther's defense of the clarity of Scripture, on the other hand, will wish first to demonstrate the external clarity of the word by showing that it is grammatically and semantically unambiguous, and secondly will define the boundary beyond which idle specu-

43. Luther maintains that the believer is not to substitute his own words for God's words: "Denn wir werden gewislich feylen, wo wir nicht einfeltiglich yhm nach sprechen, wie er uns fur spricht, gleich wie ein iung kind seym Vater den glauben odder Vater unser nach spricht ..." Vom Abendmahl Christi, Bekenntnis (1528); WA 26: 439.40-440.3 (LW 37: 296). The verb nachsprechen (repeat) is used intentionally by Luther to suggest the fraility of the human intellect in matters of faith.

44. De servo arbitrio (WA 18:653.2-9 [ $L W 33: 90]$ ): „Neque illos probo, qui refugium suum ponunt in iactantia spiritus. Nam satis acre mihi bellum isto anno fuit et adhuc est cum istis Phanaticis, qui scripturas suo spiritui subiiciunt interpretandas, quo nomine et Papam hactenus insectatus sum, in cuius regno hac voce nihil vulgatius aut receptius est, Scripturas esse obscuras et ambiguas, oportere spiritum interpretem ex sede Apostolica Romae petere, cum nihil perniciosius dicit possit, quod hinc homines impii sese supra Scripturas extulerint et ex ipsa fecerint, quicquid collibitum fuit." lation would begin, in order that the intellect be confronted with its soteriological impotence and then led to receive internal clarity as well.45

45. A brief look at Luther's defense of his interpretation of the words of institution, "This is my body," in his Vom Abendmahl Christi, Bekenntnis (1528) illustrates how this hermeneutics of the cross works. Luther begins with the uncompromising assertion that the text is clear: "Denn der text mus ia einerley und einfeltig sein und einen einigen gewissen verstand haben, sol er klar und einen gewissen artikel grunden." (WA 26: 262.31-3 [ $L W 37: 163]$.) That the words are univocal is an unmetaphysical assertation whose proof lies concretely in the conventions established by the linguistic community: "Denn wenn ich sage: Christus ist Gottes lamb, kans nicht sein, das einer durchs lamb einen wolff, der ander ein schaff verstehe, einer mus liegen, Und ist nicht beydes vom heiligen geist." (WA 26: 264.27-30 [ $L W$ 37: 165].) Applying that most basic logical rule of contradictions, Luther argues that the word "lamb" cannot be mistaken for the meaning "wolf" - language as a given order does not allow for this confusion. In the same way Luther argues against Oecolampadius, who sets "sign of the body" in place of "body": the word "body" as it stands in linguistic convention does not mean "sign of the body," and to assert their identity would be as foolish as saying Christ is Belial, or Paul is Judas (WA 26: 279.14-20 [ $L W 37: 176]$ ). Later on in the discussion Luther addresses the question of the predicatio identica de diversis naturis, which Wycliffe maintained was an impossibility (WA 26: 439.21-23 [ $L W$ 37: 295]). For Luther the problem requires no metaphysical speculation, but only the common sense of a grammarian: "Solche weise zu reden von unterschiedlichen wesen als von einerley, heissen die grammatici Synechdochen, und ist fast gemein nicht allein ynn der schriff, sondern auch ynn allen sprachen." (WA 26: 444.1-3 [ $L W 37: 301 \mathrm{f}$.].) And with his affection for everyday speech Luther gives a few examples of what the grammarians mean: "Als wenn ich einen sack odder beutel zeige odder dar reiche, sprech ich: Das sind hundert gülden, da gehet das zeigen und das wörtlin 'das' auff den beutel, Aber weil der beutel und gúlden etlicher masse ein wesen sind, als ein klumpe, so triffts zu gleich auch die gülden, Der weise nach greiffe ich ein fas an und spreche, das ist Reinisch wein, das ist Welsch wein, das ist roter wein. Item, ich greiffe ein glas an und spreche: das ist wasser, das ist bier, das ist salbe." (WA 26: 444.3-9 [ $L W 37: 302]$.) In the same way the words of institution draw on this linguistic convention: "Weil denn nu solche weise zu reden beyde inn der schrifft und allen sprachen gemein ist, so hindert uns ym abendmal die predicatio identica nichts ... und umb der sacramentlichen einickeit willen [wird] recht gered ... 'Das ist mein leib', mit dem wörtlin 'Das' auffs brod zu deuten, Denn es ist nu nicht mehr schlecht brod ym backofen, sondern fleischsbrod odder leibsbrod, das ist ein brod, so mit dem leibe Christi ein sacramentlich wesen und ein ding worden ist." (WA 26: 444.39f., 445.8-12 [LW 37: 303].) The words are clear, even if the intellect cannot grasp how this sacramental unity of body and bread actually takes place. But to try to explicate this "how" is to subject the divinely ordained word to human reason, a process of which Luther finds Wycliffe guilty when he denies the possibility of the predicatio identica. In dealing with God's works and words, maintains Luther, we are to render our reason and all cleverness captive, we are to blind ourselves and let ourselves be led and taught, so that we do not become judges of God's words (WA 26: 439.31-36 [ $L W 37: 296]$ ). The believer is to accept the words of institu- 
In summary we find that the tension between Franck's and Luther's hermeneutics arises from their differing anthropologies. Franck posits a Seelenfün lein, which, because it is ontologically identical with divine being, is capable of knowing the inner, spiritual res significata within the outer res significans. The "spiritual" or privileged nature of this inner word proves itself in its opposition to the outer word, i.e., to conventional language. Conventional language is the bearer of inner truth only insofar as it is unclear, paradoxical. The spirituallyminded exegete must overcome conventional language in his hermeneutical journey to the word hidden within the letter and, most properly, within himself. Luther, on the other hand, allows no ontological or epistemological continuum between God and humankind. First, he lowers the roof of theological knowledge to the potentia dei ordinata, thereby excluding the possibility of overcoming the word (deus revelatus in Christ and in Scripture) and reaching God himself (deus nudus). Scripture is clear because its object, Christ, has been revealed, and because it follows the rules of conventional language. Because the external word is a reliable, God-ordained witness of truth, Luther promotes the visible, institutional church in its office of proclaiming the word. But Luther, like Franck, must then explain why, if Scripture is clear, every church-goer, every person who hears the word, is not illumined by it. To explain this he distinguishes between the external and internal clarity of the word. This distinction rests on an application of his dual anthropology of simul iustus et peccator and does not introduce a spiritualistic hermeneutica gloriae. Human understanding is darkened because it seeks to define the res significata of Scripture within itself. Believers grasp salvation, for them Scripture gains internal clarity, only when they render their own intellect captive and receive that res significata lying extra se. This they do by "repeating" or confessing the words that God has already spoken through Christ, i.e., through Scripture. The burden of signification rests on God, and the believers deny themselves their own hermeneutical position.

In an age when political authority was still intertwined with, and dependent on, religious authority as in sixteenth-century Europe, the implications of Franck's hermeneutics were far more dangerous than in our own day. With the marginalization of religion to the private sphere and the institutionalization of religious tolerance in Western democratic constitutions, Franck's concept of the inner word seems to be more at home in our age than his own. His linguistic scepticism and concomitant criticism of all institutionalized authority also

tion simply as they are written and thus make God, as their source of signification, responsible for the final explanation of how body and bread reside together. strike the modern as anticipatory, since criticism has, since the Enlightenment, become the preferred intellectual method of exposing ideology.

Luther's affirmation of conventional language contains, by contrast, a certain linguistic pragmatism that has facilitated the institutionalization of his theology in the form of a Lutheran Church. But his hermeneutical model finds little resonance in the two most dominant discourses of the modern era: that of science and that of individualism. Both of these offer a self-contained system of signification: science verifies its language through empirical observation, while individualism verifies its language with an appeal to the subject. Luther's model resists appropriation into either of these discourses because it is by intention not self-contained, but depends on an authority posited outside itself and outside the bounds of human reason or feeling.

\section{Priscilla Hayden-Roy}

Department of Modern Languages and Literatures

University of Nebraska

Lincoln, Nebraska 68508-0315

\section{ZUSAMMENFASSUNG}

Der Beitrag befaßt sich mit zwei divergierenden Auffassungen der Schrift in der Reformationszeit: auf der einen Seite die spiritualistische Auffassung der Schrift als Rätsel und Paradoxon, wie sie Sebastian Franck vertritt, auf der anderen Seite Martin Luthers Annahme der Klarheit der Schrift. Diese hermeneutischen Grundpositionen gründen sich auf zwei verschiedene theologische Anthropologien. Von der mystischen Tradition übernimmt Franck den Begriff des Seelenfünkleins (synteresis), auf Grund dessen er sowohl ontologische als auch epistemologische Kontinuität zwischen Gott und Mensch voraussetzt. Dieses göttliche Erkenntnisvermögen ist dazu imstande, die innere, spirituelle res significata innerhalb des äußerlichen Schriftworts (res significans) zu begreifen. Nach Franck zeigt sich die Überlegenheit des spirituellen Sinnes gerade durch dessen Gegensätzlichkeit zum äußerlichen Buchstaben. Sprache, auch Bibelsprache, ist nur insofern Träger spiritueller Wahrheit, als sie unklar, paradox ist. Luthers Auffassung der radikalen Sündhaftigkeit des Menschen, auch nach der Rechtfertigung (simul iustus et peccator), schließt die Möglichkeit spiritueller Erkenntnis im Sinne Francks aus. Analog der nominalistischen Unterscheidung zwischen der potentia dei absoluta und potentia dei ordinata differenziert Luther zwischen dem verborgenen und geoffenbarten Gott; sowohl das Wort (res significans) als auch dessen Bedeutung (res significata) sind nach Christi Tod und Auferstehung offenbar. Der Exeget dringt nicht wie bei Franck durch das Wort hindurch zum verborgenen, dem Buchstaben entgegengesetzten göttlichen Wissen, sondern faßt allein die durch die Konventionalität der Sprache festgelegte, offenbare Bedeutung des Wortes. Damit erfaßt er auch die res significata, das geoffenbarte Wort Gottes. Luthers Unterscheidung $z$ wischen äußerer und innerer Klarheit beruht auch auf seiner 
Anthropologie: Dem wesentlich sündhaften Menschen wird die Schrift erst dann klar, wenn er seinen eigenen Verstand gefangen gibt und die res significata extra se durch den Glauben annimmt. Durch das Nachsprechen von Gottes Wort bekennt der Gläubige die Wahrheit des Wortes; er verzichtet auf eine eigene, in sich selbst gegründete hermeneutische Position. Schließlich trägt allein Gott die "Signifikationslast" des Wortes. 